Vol. 1 No. 2, September 2020

P-ISSN: 2746-0967, E-ISSN: 2721-656X

\title{
Konsep Rehabilitasi Bagi Pengguna Narkotika yang Berkeadilan
}

\section{Siti Hidayatun, Yeni Widowaty}

Kejaksaan Tinggi Yogyakarta, ${ }^{1}$ Magister Hukum Pascasarjana UMY ${ }^{2}$

E-mail: sitihidayatun.sh@gmail.com, ${ }^{1}$ yeniwidowaty@umy.ac.id ${ }^{2}$

\section{INFO ARTIKEL \\ Perjalanan Artikel: \\ Artikel Dikirimkan oleh penulis: 17-06-20 \\ Artikel Direview: 22-06-20 \\ Artikel Direvisi: 02-07-20 \\ Artikel Diterima atau \\ Dipublikasikan: 24-08-20}

DOI: 10.18196/jphk.1209

\begin{abstract}
ABSTRAK
Penelitian ini dilakukan untuk mengkaji rehabilitasi bagi pengguna narkotika di Daerah Istimewa Yogyakarta. Penelitian yuridis empiris menemukan fakta bahwa rehabilitasi bagi pengguna narkotika di DIY sudah sesuai dengan hukum positif yang berlaku di Indonesia. Penyidik dapat melakukan rehabilitasi bagi pengguna narkotika berdasar Pasal 54 Undang-Undang Nomor 35 Tahun 2009 tentang Narkotika. Tersangka akan dilakukan proses rehabilitasi dalam perkara narkotika, harus terlebih dahulu melalui proses assesment medis dan hukum. Konsep yang diusulkan penulis mengenai pelaksanaan rehabilitasi yang berkeadilan bagi pengguna narkotika adalah seharusnya terhadap setiap pengguna narkotika yang telah memenuhi persyaratan dalam Pasal 54 Undang-undang Nomor 35 Tahun 2009 tentang Narkotika dan Peraturan Kepala BNN No. 11 Tahun 2014 seluruhnya dilakukan rehabilitasi, karena pidana penjara bagi pengguna narkotika bukan solusi yang baik dan berkeadilan.
\end{abstract}

Kata Kunci: Narkotika, Keadilan, Rehabilitasi.

\section{Pendahuluan}

Persoalan penyalahgunaan narkotika semakin lama semakin meningkat dengan adanya penyelundupan, peredaran dan perdagangan gelap, penyalahgunaan dan ditindaklanjuti dengan adanya penangkapan, penahanan terhadap para pelaku penyalahgunaan maupun para pengedar narkotika. Upaya penanggulangan masalah narkotika, tidaklah cukup dengan satu cara melainkan harus dilaksanakan dengan rangkaian tindakan yang berkesinambungan dari berbagai macam unsur, baik dari lembaga pemerintah maupun non pemerintah. Rangkaian tindakan tersebut mencakup usaha-usaha yang bersifat preventif, represif dan rehabilitatif.

Rehabilitasi merupakan salah satu upaya pemerintah dalam menanggulangi penyalahgunaan narkotika. Upaya ini merupakan upaya atau tindakan alternatif, karena pelaku penyalahgunaan narkotika juga merupakan korban kecanduan narkotika yang memerlukan pengobatan atau perawatan. Pengobatan atau perawatan ini dilakukan melalui fasilitas rehabilitasi. Penetapan rehabilitasi bagi 
pecandu narkotika merupakan pidana alternatif yang dijatuhkan oleh hakim dan diperhitungkan sebagai masa menjalani hukuman.

Pemerintah telah menetapkan peraturan tentang narkotika dalam UndangUndang Nomor 35 Tahun 2009 tentang Narkotika yang dalam Pasal 5 ditentukan bahwa pengaturan Narkotika dalam Undang-undang ini meliputi segala bentuk kegiatan dan/atau perbuatan yang berhubungan dengan Narkotika dan Prekursor Narkotika.

Sebenarnya telah ada peraturan yang melarang adanya penyalahgunaan narkotika, tetapi dalam kenyataannya penyalahgunaan narkotika tetap ada, bahkan sekarang ini persoalan narkotika menjadi masalah serius bagi bangsa Indonesia. Penyalahgunaan narkotika inilah yang membahayakan karena akan membawa pengaruh terhadap diri si pemakai, di mana ia akan kecanduan dan hidupnya akan tergantung pada zat-zat narkotika, yang jika tidak tercegah (terobati), jenis narkotika yang digunakan akan semakin kuat dan semakin besar dosisnya sehingga akan memperparah keadaan diri pecandu. ${ }^{1}$

Pasal 54 Undang-undang Nomor 35 Tahun 2009 tentang Narkotika, yang menentukan: "Pecandu Narkotika dan korban penyalahgunaan Narkotika wajib menjalani rehabilitasi medis dan rehabilitasi sosial". Pasal 57 Undang-Undang Nomor 35 Tahun 2009 menyatakan "Selain melalui pengobatan dan/atau rehabilitasi medis, penyembuhan Pecandu Narkotika dapat diselenggarakan oleh instansi pemerintah atau masyarakat melalui pendekatan keagamaan dan tradisional".

Implementasi rehabilitasi merupakan realisasi dari sebuah aturan, hal ini sangat penting karena dengan sebuah implementasi dapat diketahui apakah suatu aturan tersebut sudah benar-benar terlaksana atau tidak. Undang-undang Nomor 35 Tahun 2009 tentang narkotika telah memberi perlakuan yang berbeda bagi pelaku penyalahguna narkotika, sebelum undang-undang ini berlaku tidak ada perlakuan yang berbeda antara pengguna, pengedar, bandar maupun produsen narkotika. Pengguna atau pecandu narkotika di satu sisi merupakan pelaku tindak pidana, namun di sisi lain merupakan korban. ${ }^{2}$

Kenyataannya menunjukkan penjatuhan vonis oleh hakim dalam perkara narkotika masih belum efektif pelaksanaannya. Sebagian besar pecandu narkotika tidak dijatuhi vonis rehabilitasi sesuai yang disebutkan dalam Undang-undang Narkotika melainkan dijatuhi vonis penjara meskipun ketentuan Undang-undang menjamin pengaturan upaya rehabilitasi, baik itu rehabilitasi medis maupun rehabilitasi sosial bagi penyalahguna dan pecandu narkotika. Dalam Undang-

\footnotetext{
${ }^{1}$ SoedjonoDirdjosisworo. (2010). Narkotika dan Remaja. Bandung:Alumni, hlm. 24.

${ }^{2}$ Kusno Adi. (2009). Diversi Sebagai Upaya Alternatif Penanggulangan Tindak Pidana Narkotika Oleh Anak. Malang: UMM Press, hlm.3
} 
Undang Narkotika ketentuan hukum yang mengatur mengenai rehabilitasi terhadap pecandu narkotika diatur dalam Pasal 54, Pasal 56, Pasal 103, dan dikaitkan dengan Pasal 127 Undang-undang Narkotika. Hal yang menarik dalam Undangundang Narkotika terdapat dalam Pasal 103 dimana kewenangan hakim untuk menjatuhkan vonis/sanksi bagi seseorang yang terbukti sebagai pecandu narkotika untuk menjalani rehabilitasi.

Upaya penanggulangan kejahatan yang tepat sebaiknya tidak hanya terfokus pada berbagai hal yang berkaitan dengan penyebab timbulnya kejahatan tetapi metode apa yang efektif dipergunakan dalam penanggulangan kejahatan. ${ }^{3}$ Pemberian rehabilitasi terhadap penyalahguna narkotika dianggap perlu untuk menekan penggunaan terhadap narkotika dan obat-obatan terlarang.

Rehabilitasi dan penjatuhan pidana kerap kali dipandang sebagai dua hal yang berseberangan. Para pendukung rehabilitasi senantiasa mengemukakan sejumlah alasan mengapa rehabilitasi jauh lebih baik dibandingkan dengan penjatuhan pidana penjara, demikian pula sebaliknya. Artikel berjudul Punishment Fails, Rehabilitation Works, yang ditulis oleh James Gilligan, profesor dari New York University memberikan ilustrasi betapa hukuman penjara tidak lagi efektif di Amerika Serikat. ${ }^{4}$ Bahkan rehabilitasi yang telah sekian dekade tidak diterima sebagai suatu teori penghukuman (theory of punishment) telah diusung oleh Supreme Court di Amerika Serikat pada kasus Graham v Florida di tahun 2010. ${ }^{5}$

Seorang pecandu narkotika, dapat menjalani pengobatan dan atau perawatan melalui fasilitas rehabilitasi setelah ada ketetapan atau keputusan dari hakim. Hakim dalam penegakan hukum memutus seorang pecandu narkotika menjalani rehabilitasi harus sesuai dengan prinsip keadilan. Ketetapan atau keputusan ini didasarkan pada keterangan dari pihak keluarga atau Rumah Sakit (Dokter). Selama masa rehabilitasi diadakan pengawasan dan pemantauan sampai pecandu benar-benar sembuh dan bebas dari kecanduan narkotika. Dalam rehabilitasi ini yang lebih penting adalah bagaimana si korban dapat bertahan dari kesembuhan, tidak kambuh lagi sepulang dari panti pengobatan dan rehabilitasi tersebut. Seorang pecandu dapat menjalani rehabilitasi medis sekaligus sosial.

Berdasarkan uraian pada pendahuluan di atas, maka permasalahan dalam penelitian ini ialah:

\footnotetext{
${ }^{3}$ Sujono AR dan Daniel Bony. (2011). Komentar dan Pembahasan Undang-undang Nomor 35 Tahun 2009 tentang Narkotika. Jakarta: Sinar Grafika, hlm. 33

4James Gilligan, 2012, Punishment Fails, Rehabilitation Works, 19 December 2012, dalam http://www.nytimes.com/roomfordebate/2012/12/18/prison-could-be-productive/ punishment-fails-rehabilitation-works

${ }^{5}$ Allegra M. Mcleod. (2012). Decarceration Courts, Possibilities and Perils of a Shifting Criminal Law. The Georgetown Law Journal, Vol. 100, No.1587, hlm. 1604
} 
a. Apakah rehabilitasi bagi pengguna narkotika sudah sesuai dengan hukum positif?

b. Bagaimana konsep ke depan atau solusi mengenai pelaksanaan rehabilitasi bagi pengguna narkotika yang berkeadilan?

\section{Metodologi}

Jenis penelitian dalam penelitian ini adalah penelitian yuridis empiris, yaitu penelitian dengan mendasarkan pada data primer sebagai sumber data utamanya dan data sekunder sebagai pelengkap. Pendekatan penelitian yang diterapkan dalam penelitian ini adalah deskriptif analitis, yakni penelitian yang sifatnya hanya menggambarkan keseluruhan keadaan objek penelitian dan bersifat analitis dengan kegiatan mengelompokkan, dan mengkategorisasikan data disesuaikan dengan tujuan penelitian dan menjawab permasalahan dalam penelitian. ${ }^{6}$ Data Primer diperoleh langsung dari RS Ghrasia Sleman Yogyakarta, Ditresnarkoba Polda DIY, Kejaksaan Tinggi DIY, Kejaksaan Negeri Yogyakarta, serta BNNP DIY, sedangkan data sekunder diperoleh dengan penelitian kepustakaan. Teknik pengumpulan data dalam penelitian ini dilakukan dengan cara wawancara narasumber dengan menggunakan pedoman wawancara dan studi dokumen.

Data yang telah dikumpulkan dan disistematisir kemudian dilakukan analisis secara kualitatif, dengan langkah-langkah, sebagai berikut: pertama, klasifikasi data disesuaikan dengan permasalahan dalam penelitian; kedua, sistematisasi hasil klasifikasi data; ketiga, evaluasi data, yakni memberikan argumentasi pada data; dan keempat, analisis, dianalisis untuk dijadikan dasar dalam pengambilan kesimpulan.

\section{Analisis dan Hasil}

\subsection{Pengertian Tindak Pidana Narkotika}

Secara umum, yang dimaksud dengan narkotika adalah sejenis zat yang dapat menimbulkan pengaruh-pengaruh tertentu bagi orang-orang yang menggunakannya, yaitu dengan cara memasukkan ke dalam tubuh. ${ }^{7}$ Istilah narkotika yang dipergunakan di sini bukanlah "narcotics" pada farmacologie (farmasi), melainkan sama artinya dengan "drug", yaitu sejenis zat yang apabila dipergunakan akan membawa efek dan pengaruh-pengaruh tertentu pada tubuh si pemakai, yaitu:

a. Mempengaruhi kesadaran;

b. Memberikan dorongan yang dapat berpengaruh terhadap perilaku manusia

${ }^{6}$ Soerjono Soekanto. (2010). Pengantar Penelitian Hukum. Jakarta: UI Press, hlm. 10

${ }^{7}$ Hari Sasangka. (2013). Narkotika dan Psikotropika Dalam Hukum Pidana. Bandung:Mandar Maju, hlm. 33 
c. Pengaruh-pengaruh tersebut dapat berupa :

1) Penenang

2) Perangsang (bukan rangsangan sex)

3) Menimbulkan halusinasi (pemakainya tidak mampu membedakan antara khayalan dan kenyataan, kehilangan kesadaran akan waktu dan tempat). ${ }^{8}$

Sehubungan dengan pengertian narkotika, menurut Sudarto dalam bukunya Kapita Selekta Hukum Pidana mengatakan bahwa perkataan "narkotika berasal dari perkataan Yunani "Narke", yang berarti terbius sehingga tidak merasa apa-apa". ${ }^{9}$

Menurut Soedjono Dirjosisworo, narkotika atau yang sering diistilahkan dengan drug adalah sejenis zat yang bisa menimbulkan pengaruhpengaruh tertentu bagi mereka yang menggunakan dengan memasukkannya ke dalam tubuh. Pengaruh tersebut berupa pembiusan, hilangnya rasa sakit, rangsangan semangat dan halusinasi atau timbulnya khayalan-khayalan. ${ }^{10}$

Pengaturan ketersediaan narkotika bertujuan untuk mencegah dan menghindari adanya penyalahgunaan dan peredaran gelap narkotika. Penyalahgunaan narkotika dapat diartikan sebagai

"Pemakaian narkotika secara tetap yang bukan tujuan untuk pengobatan, atau yang digunakan tanpa mengikuti aturan takaran pemakaian". Sedangkan peredaran gelap narkotika adalah setiap kegiatan atau serangkaian kegiatan yang dilakukan secara tanpa hak dan melawan hukum yang ditetapkan sebagai tindak pidana narkotika. ${ }^{11}$

Menurut Pasal 1 angka 1 Undang-Undang Nomor 35 Tahun 2009 tentang Narkotika menentukan bahwa narkotika adalah zat atau obat yang berasal dari tanaman atau bukan tanaman, baik sintesis maupun semi sintesis, yang dapat menyebabkan penurunan atau perubahan kesadaran, hilangnya rasa, mengurangi sampai menghilangkan rasa nyeri dan dapat menimbulkan ketergantungan, yang dibedakan ke dalam golongan-golongan sebagaimana terlampir dalam Undangundang ini.

\footnotetext{
8Soedjono Dirdjosisworo. (2011). Segi Hukum tentang Narkotika di Indonesia. Bandung: Karya Nusantara, hlm. 14

${ }^{9}$ Djoko Prakoso, dkk. (2012). Kejahatan-Kejahatan Yang Merugikan dan Membahayakan Negara. Jakarta: Bina Aksara, hlm. 480 ${ }^{10}$ Soedjono Dirdjosisworo. (2010). Hukum Narkotika Indonesia. Bandung: Citra Aditya Bakti, hlm. 3.

11I Danny Yatim. (2011). Kepribadian, Keluarga dan Narkotika, Tinjauan Sosial-Psikologis. Jakarta: Arcan, hlm. 5
} 
Jenis-jenis narkotika di dalam Undang-undang Nomor 35 Tahun 2009 pada Bab III Ruang Lingkup Pasal 6 ayat (1) menyebutkan bahwa narkotika digolongkan menjadi: ${ }^{12}$
a. Narkotika Golongan I;
b. Narkotika Golongan II; dan
c. Narkotika Golongan III.

\subsection{Rehabilitasi bagi Pengguna Narkotika Sesuai dengan Hukum Positif Indonesia}

Sasaran pembinaan terpidana perkara narkotika sebetulnya lebih ditujukan kepada kelompok pemakai/pecandu yang menjadi korban kejahatan dari para pemasok/pengedar narkotika tersebut. Berdasarkan hal tersebut, para terpidana setelah diketahui segala sesuatunya tentang proses peradilan, maka pola pembinaannya diserahkan kepada lembaga pemasyarakatan di mana mereka menjalani masa hukuman.

Secara keseluruhan program pembinaan narapidana dapat dibagi menjadi 2 (dua), yaitu:

a. Program untuk mengembalikan kesehatan, baik fisik maupun psikologis

b. Program untuk penambahan wawasan pengetahuan, baik pengetahuan agama maupun pengetahuan umum lainnya.

Program untuk mengembalikan kesehatan, baik fisik maupun psikologis, pada umumnya lembaga pemasyarakatan mengatur waktu untuk mengadakan kegiatan seperti berkebun, bekerja keterampilan, berolah raga, dan lain sebagainya. Sedangkan penjabaran program penambahan wawasan pengetahuan biasanya dilakukan dengan mendengarkan ceramah yang diselenggarakan oleh petugas lembaga pemasyarakatan atau mengadakan kegiatan pengajian dan diskusi-diskusi, baik secara berkelompok maupun perorangan.

Rehabilitasi narkotika menurut UU No. 35 Tahun 2009 terdiri dari rehabilitasi medis yaitu suatu proses kegiatan pengobatan secara bidang pemberantasan BNNP DIY untuk membebaskan pecandu dari ketergantungan Narkotika, dan rehabilitasi sosial yaitu kegiatan pemulihan secara terpadu, baik fisik, mental maupun sosial, agar bekas pecandu Narkotika dapat kembali melaksanakan fungsi sosial dalam kehidupan masyarakat. Penyidik dapat mengajukan permohonan assessment kepada Tim Assessment Terpadu (TAT) untuk dapat dan tidaknya seorang tersangka dilakukan rehabilitasi, hal ini diatur dalam peraturan BNN No. 11 Tahun 2014. Assesment yang dilakukan oleh Tim Assessment Terpadu (TAT) terdiri dari assessment medis dan assessment hukum. Menurut Pasal 3 ayat (1) seseorang dapat dilakukakan rehabilitasi jika seseorang tersebut merupakan pecandu narkotika dan korban

12 Undang-Undang Nomor 22 Tahun 1997 tentang Narkotika. 
penyalahguna narkotika. Menurut Pasal 3 ayat (2) dalam hal seseorang sebagai tersangka dalam perkara narkotika dapat dilakukan rehabilitasi setelah mendapat rekomendasi dari Tim Assessment Terpadu (TAT) peraturan BNN No. 11 Tahun 2014. Berdasarkan Pasal 9 ayat (2), Tim Asesmen Terpadu terdiri dari:

a. Tim Dokter yang meliputi Dokter dan Psikolog yang telah memiliki sertifikasi asesor dari Kementerian Kesehatan;

b. Tim Hukum yang terdiri dari unsur Polri, BNN, Kejaksaan dan Kementerian Hukum dan HAM.

Assessment bertujuan agar Pecandu Narkotika dan Korban Penyalahgunaan Narkotika yang tanpa hak dan melawan hukum yang telah ditetapkan sebagai Tersangka untuk dapat menjalani rehabilitasi serta mengatur pelaksanaan penempatan Tersangka ke dalam lembaga rehabilitasi sehingga dapat dilakukan secara tepat, transparan, dan akuntabel, berdasarkan rekomendasi dari Tim Asesmen Terpadu.

Berdasarkan Pasal 11 Peraturan BNN No. 11 Tahun 2014 tentang Tata Cara Penanganan Tersangka dan/atau Terdakwa Pecandu Narkotika dan Korban Penyalahgunaan Narkotika ke Dalam Lembaga Rehabilitasi, Tim assessment terpadu dibentuk oleh BNN secara berjenjang dari tingkat pusat sampai tingkat daerah (kabupaten/Kota) dan dibawah koordinasi dari BNN melalui surat keputusan kepala BNN/BNNP/BNNK.

Berdasarkan Pasal 14 Peraturan BNN No. 11 Tahun 2014 tentang Tata Cara Penanganan Tersangka dan/atau Terdakwa Pecandu Narkotika dan Korban Penyalahgunaan Narkotika ke Dalam Lembaga Rehabilitasi mengatakan bahwa seorang pelaku tindak pidana narkotika dapat di rehabilitasi setelah mendapat rekomendasi dari tim assessment terpadu sebelum dilakukan penahanan oleh penyidik, karena penyidik harus mengirimkan permohonan assessment paling lambat 1x24 jam setelah melakukan penangkapan, kemudian hasil assessment diserahkan paling lama 6 (enam) hari kepada Penyidik untuk dilaporkan secara tertulis kepada Pengadilan Negeri setempat.

Berdasarkan data dari RS Ghrasia Sleman Yogyakarta, ${ }^{13}$ diperoleh keterangan bahwa jumlah pasien rehabilitasi rawat inap pada Instalasi Rehabilitasi Napza Rumah Sakit Grhasia dari tahun ke tahun mengalami peningkatan. Adapun jumlah pasien rehab rawat inap Instalasi Rehabilitasi Napza RS Grhasia dari tahun 2017-2019 adalah sebagai berikut;

\footnotetext{
${ }^{13}$ Data dari RS Ghrasia Sleman Yogyakarta.
} 
Tabel 1

Jumlah Pasien Rehab Rawat Inap Instalasi Rehabilitasi Napza RS Ghrasia

\begin{tabular}{|l|c|c|c|}
\hline No & Tahun & Jumlah & Keterangan \\
\hline 1 & 2017 & 72 & Rehab \\
\hline 2 & 2018 & 80 & Rehab \\
\hline 3 & 2019 & 82 & Rehab \\
\hline
\end{tabular}

Sumber: RS Ghrasia, 2020

Berdasarkan data tersebut di atas, dapat dilihat bahwa dari tahun 2017 sampai 2019 jumlah pasien rehab rawat inap di Instalasi Rehabilitasi Napza RS Ghrasia mengalami kenaikan yang signifikan. Pelaksanaan rehabilitasi bagi pengguna narkotika di Instalasi Rehabilitasi Napza RS Ghrasia sudah sesuai dengan Teori Keadilan dan Teori Kemanfaatan Hukum. Sesuai dengan teori keadilan dan kemanfaatan hukum dikarenakan penerapan assesmen dalam penetapan rehabilitasi di Instalasi Rehabilitasi Napza RS Ghrasia sudah sesuai dengan peraturan perundang-undangan. Prosedur assesmen yang digunakan yaitu setelah dilakukan penangkapan terhadap terduga penyalahguna narkotika, lalu dilakukan pemeriksaan urine, apabila hasil pemeriksaan tersebut membuktikan bahwa urine terbukti positif maka penyidik akan melaksanakan gelar perkara untuk dapat diajukan rehabilitasi ke BNNP (Badan Nasional Narkotika Propinsi). Jumlah berat barang bukti narkotika sangat berpengaruh dalam proses assesment untuk menentukan rehabilitasi. Hal ini diatur Surat Edaran Mahkamah Agung Nomor : 04 tahun 2010 tentang penempatan penyalahgunaan, korban penyalahgunaan dan pecandu narkotika ke dalam lembaga rehabilitasi medis dan rehabilitasi sosial, dan Surat Edaran Bareskrim Polri Nomor : SE/01/II/2018/Bareskrim tentang petunjuk rehabilitasi bagi pecandu narkotika dan korban penyalahgunaan narkotika.

Rehabilitasi tersebut benar-benar telah diperhitungkan sebagai masa menjalani hukuman, sebagaimana diatur dalam Pasal 54 Undang-Undang Nomor 35 Tahun 2009 tentang Narkotika yang menyatakan bahwa pecandu Narkotika dan korban penyalahgunaan Narkotika wajib menjalani rehabilitasi medis dan rehabilitasi sosial. Pelaku atau korban kecanduan narkotika selain sebagai pelaku tindak pidana narkotika yang harus dijatuhi pidana seperti halnya terhadap pelaku tindak pidana lainnya juga harus menjalani pengobatan atau perawatan melalui fasilitas rehabilitasi yang meliputi rehabilitasi medis dan sosial sehingga masa menjalani pengobatan dan atau perawatan ini diperhitungkan sebagai masa menjalani hukuman. 
Adapun langkah-langkah yang pertama dilakukan adalah pihak Rumah Sakit penyelenggara Rehabilitasi bagi Pengguna Narkotika akan melakukan diagnosa terhadap pasien, setelah dilakukan diagnosa kemudian dilakukan rehabilitasi medis yaitu dengan 2 cara:

a. Dengan terapi Simptomatis, yaitu dilakukan tindakan medis terhadap pasien dengan melihat gejala-gejala yang dialami pasien, misalnya pasien mengalami nyeri akibat pemakaian narkotika

b. Dengan terapi Substitusi, yaitu dilakukan tindakan medis terhadap pasien dengan memberikan penggantian obat yang hampir mirip narkotika yang sering di konsumsi oleh pasien tetapi obat tersebut tidak menimbulkan ketergantungan hanya saja sebagai pengganti agar pasien tidak kecanduan lagi. Obat yang biasanya diberikan kepada pasien sebagai obat pengganti ada 3 yaitu Kodein, Subutex dan Metadon.

Setelah keadaan pasien stabil kemudian dilanjutkan dengan rehabilitasi sosial yang dilakukan dengan cara pembinaan mental dan spiritual yaitu dengan dilakukan pencerahan rohani, pengajian, pembentukan kepribadian pasien dan terapi sharing feeling, yaitu diadakan suatu forum tanya jawab terhadap pasien tentang perasan yang sedang dialami pasien. Adapun fase dari rehabilitasi sosial dilakukan sebagai berikut:

a. Induksi

Yaitu sambil memulihkan kesehatan setelah detoksifikasi, residen harus mulai mengenal rumah, staff, peraturan dan menyesuaikan diri dengan cara hidup yang baru. Pada akhir fase ini residen harus memutuskan tetap mengikuti program atau keluar dari program.

b. Primary Stage

Residen belajar menghormati aturan, belajar menyelesaikan konflik seharihari dengan sesama anggota komunitas dan bertanggung jawab dengan tugas-tugas yang diterima. Pengolahan emosi adalah salah satu tujuan terpenting dalam fase ini. Nilai-nilai kejujuran, rasa hormat dan tanggung jawab diuji dalam hidup konkrit berkomunitas.

c. Re-Entry Stage

Ini adalah tahap pemulihan fisik dan pemulihan psikis agar mampu berinteraksi di dalam keluarga dan masyarakat.

Waktu yang diperlukan untuk melakukan rehabilitasi medis kurang lebih 2 (dua) minggu sampai 1 (satu) bulan. Sedangkan waktu yang diperlukan untuk melaksanakan rehabilitasi sosial waktu yang dibutuhkan kurang lebih 9 (sembilan) bulan sampai 1 (satu) tahun. Dan yang menanggung biaya selama menjalani masa 
rehabilitasi adalah pihak keluarga pasien tetapi apabila keluarga pasien tidak mampu maka dapat mengajukan permohonan kepada pihak Rumah Sakit penyelenggara Rehabilitasi bagi Pengguna Narkotika dengan Askeskin yaitu Asuransi Kesehatan Keluarga Miskin.

Selain itu ada kontrol dari pihak Kepolisian ke Rumah Sakit penyelenggara Rehabilitasi bagi Pengguna Narkotika itu sendiri untuk mengamati jalannya/pelaksanaan rehabilitasi. Apabila para residen sudah keluar dari Rumah Sakit penyelenggara Rehabilitasi bagi Pengguna Narkotika tersebut maka bukan berarti tugas dari pendamping sudah selesai. Namun para pandamping harus mengawasi pergaulan dari residen sendiri serta siap untuk mendengarkan keluh kesah dari residen sendiri dengan menggunakan alat komunikasi yang ada minimal 2 (dua) bulan untuk/supaya residen dapat menyesuaikan diri terhadap lingkungan sekitar.

\subsection{Konsep Rehabilitasi Pengguna Narkotika yang Berkeadilan}

Mencermati perkembangan di beberapa negara, muncul paradigma baru dalam memandang pengguna/pecandu narkotika yang tidak lagi dipandang sebagai perilaku jahat (kriminal) tetapi sebagai orang yang pengidap penyakit kronis yang harus mendapatkan perawatan dan pemulihan secara bertahap. Paradigma ini selanjutnya menciptakan kebijakan baru dalam menangani korban pengguna narkotika yang tidak lagi diproses secara hukum, tetapi langsung membawa pengguna/pecandu ke pusat rehabilitasi.

Dengan kata lain paradigma ini mengarah pada upaya dekriminalisasi bagi pengguna narkotika. Penerapan hukum pidana berupa pidana penjara bagi korban pengguna narkotika terbukti tidak berhasil, yang sesungguhnya terjadi justru setiap tahun korban pengguna narkotika yang dijatuhi pidana penjara angkanya semakin naik. Hal inilah yang perlu dikaji ulang terkait tujuan dan fungsi penerapan hukum pidana bagi korban pengguna narkotika. Faktor terpenting dalam upaya penanggulangan penyalahgunaan narkotika yang justru seringkali diabaikan terutama oleh aparat penegak hukum di Indonesia adalah adanya upaya rehabilitasi. Model pemidanaan terhadap korban pengguna narkotika sampai sekarang ini masih menempatkan sebagai pelaku tindak pidana (kriminal), sehingga upaya-upaya rehabilitatif sering terabaikan.

Di Indonesia pola semacam itu belum diterapkan, korban pengguna narkotika masih dimasukkan ke dalam penjara, meskipun selama proses tahanan diperkenankan untuk direhabilitasi, namun belum menjadi solusi efektif. Sistem hukum di Indonesia harus mulai melakukan kebijakan dengan langsung membawa korban pengguna narkotika ke tempat rehabilitasi. Apabila korban pengguna 
narkotika ditangkap polisi atau dilaporkan orang tua dan/atau wali maka mereka harus ditempatkan di tempat rehabilitasi.

Berdasarkan hasil wawancara penulis dengan dr. Kuncoro, selaku Kepala Seksi Rehabilitasi RS Ghrasia Sleman Yogyakarta, ${ }^{14}$ diperoleh keterangan bahwa pihak RS tidak mengetahui proses pelaksanaan penahanan di Rutan/Lembaga Pemasyarakatan untuk perbandingan lebih baik tidaknya terhadap rehabilitasi NAPZA. Dengan adanya rehabilitasi, seseorang/tersangka yang terlibat dalam perkara narkoba nantinya dapat menyadari dan mengerti serta akan meninggalkan dunia narkotika.

Menurut dr. Kuncoro, selaku Kepala Seksi Rehabilitasi RS Ghrasia Sleman Yogyakarta,15 RS Ghrasia tidak menerima rehabilitasi untuk anak-anak. Sesuai dengan tujuan diadakannya rehabilitasi RS Grhasia membantu mengupayakan penyalahgunaan narkotika untuk terbebas dari ketergantungannya, mengubah pola pikirnya menjadi pola pikir yang sehat, perilaku sehat dan berani bersikap untuk menjalani kehidupan tanpa narkotika saat kembali kepada keluarga dan masyarakat.

Berdasarkan hasil wawancara penulis dengan Pudji Cahyono, SE, selaku Kabagwassidik Ditresnarkoba Polda DIY juga sebagai Penyidik Narkotika Polda DIY,16 diperoleh keterangan bahwa konsep ke depan mengenai pelaksanaan rehabilitasi bagi pengguna narkotika yang berkeadilan adalah bahwa semua pengguna narkotika baik itu korban, pecandu maupun pemakai pemula narkotika berhak untuk mendapatkan kesempatan untuk direhabilitasi. Sehingga untuk memenuhi hal ini maka pemerintah harus menyediakan anggaran yang cukup. Selain itu pemerintah juga harus menyediakan tempat rehabilitasi yang representative dimana tempat tersebut harus dipisahkan antara pengguna sebagai korban, pecandu maupun pemula. Setelah menjalani assesment dan dinyatakan memenuhi syarat untuk dilakukan rehabilitasi maka kemudian tersangka diantar ke tempat rehabilitasi yang sudah ditunjuk oleh BNN. Pengawasan pada saat menjalani proses rehabilitasi dilakukan oleh Pihak-pihak yang sudah ditunjuk untuk melaksanakan rehabilitasi.

Berdasarkan hasil wawancara penulis dengan M. Mardiyono, selaku Kasubdit 3 Ditresnarkoba Polda DIY juga sebagai Penyidik Narkotika Polda DIY,17

14 Wawancara dengan dr. Kuncoro, selaku Kepala Seksi Rehabilitasi RS Ghrasia Sleman Yogyakarta, pada tanggal 8 Oktober 2019

${ }^{15}$ Ibid.

16 Wawancara dengan Pudji Cahyono, SE, selaku Kabagwassidik Ditresnarkoba Polda DIY juga sebagai Penyidik Narkotika Polda DIY, pada tanggal 10 Oktober 2019

17 Wawancara dengan M. Mardiyono, selaku Kasubdit 3 Ditresnarkoba Polda DIY juga sebagai Penyidik Narkotika Polda DIY, pada tanggal 10 Oktober 2019 
diperoleh keterangan bahwa konsep ke depan atau solusi mengenai pelaksanaan rehabilitasi bagi pengguna narkotika adalah seyogyanya terhadap pengguna narkotika yang telah memenuhi persyaratan dalam Pasal 54 Undang-undang Nomor 35 tahun 2009 tentang Narkotika dan Peraturan Kepala BNN No. 11 Tahun 2014 seluruhnya dilakukan rehabilitasi, tidak ada lagi dilakukan bagi pengguna narkotika dilakukan penahanan di rutan maupun di lembaga pemasyarakatan karena bagi pengguna narkoba bukan solusi. Justru dengan dilakukannya rehabilitasi terhadap pengguna narkotika didukung dari keluarga dan masyarakat maka pengguna narkotika lambat laun bisa sembuh dari penggunaan narkotika dan bisa menjadi duta bagi pengguna narkotika.

Berdasarkan hasil wawancara penulis dengan Septana Setya Budi, SH.MH., selaku Asisten Tindak Pidana Umum Kejaksaan Tinggi DIY,18 diperoleh keterangan bahwa berdasarkan Peraturan Bersama Jaksa Agung Nomor : PER005/A/JA/03/2014 tanggal 11 Maret 2014 tentang Penanganan Pecandu Narkotika Dan Korban Penyalahgunaan Narkotika Ke Dalam Lembaga Rehabilitasi, bahwa pengawasan terhadap rehabilitasi medis penyalahguna narkotika dilakukan oleh Pimpinan Instasi Lembaga Rehabilitasi dan melaporkan perkembanganya terhadap penegak hukum yang memintakan rehabilitasi. Penjatuhan Hukuman Rehabilitasi pada saat putusan pengadilan yang telah incracht dikurangkan masa rehabilitasi yang telah dijalani selama proses pemeriksaan baik penyidikan dan atau sampai dengan penuntutan. Penempatan ke dalam lembaga rehabilitasi dapat dilakukan oleh Penyidik atau Penuntut Umum untuk kepentingan pemeriksaan ke dalam lembaga rehabilitasi yang ditunjuk oleh pemerintah atau pribadi, dengan dilengkapi Berita Acara Penempatan di lembaga rehabilitasi dan rekomendasi dari Tim Asesmen serta biaya atas proses rehabilitasi tersebut ditanggung oleh pihak pemerintah (bagi yang tidak mampu) maupun pribadi atau keluarga.

Berdasarkan hasil wawancara penulis dengan Semi Hastuti, SH., selaku Jaksa Penuntut Umum pada Kejaksaan Negeri Yogyakarta, ${ }^{19}$ diperoleh keterangan bahwa Tujuan dan manfaat pelaksanaan rehab akan lebih baik dibanding dengan pelaksanaan penahanan rutan/LP oleh karena rehab bertujuan untuk memulihkan dan /atau mengembangkan kemampuan fisik, mental dan sosial tersangka, terdakwa atau Napi dalam tindak pidana narkotika atau dengan kata lain tujuan rehab adalah mengedepankan aspek kesehatan terhadap masyarakat pengguna narkotika. Dari segi manfaat hukum, rehab lebih bermanfaat daripada hukuman penjara oleh karena dapat memulihkan pengguna seperti sediakala. Pada saat tersangka/terdakwa pada tingkat penuntutan dilakukan rehabilitasi, maka jangka

18 Wawancara dengan Septana Setya Budi, SH.MH., selaku Asisten Tindak Pidana Umum Kejaksaan Tinggi DIY, pada tanggal 15 Oktober 2019.

19 Wawancara dengan Semi Hastuti, SH., selaku Jaksa Penuntut Umum pada Kejaksaan Negeri Yogyakarta, pada tanggal 16 Oktober 2019. 
waktu rehabilitasi tersebut dihitung. Hukuman rehab merupakan model hukuman non criminal yang justru untuk menghilangkan atau setidak-tidaknya menahan bisnis narkotika baik dari sisi demand maupun sisi supply. Dasar hukum Pasal 103 ayat (2) UU Nomor 35 Tahun 2009 tentang Narkotika yang menegaskan masa menjalani pengobatan dan/atau perawatan bagi pecandu narkotika sebagaimana dimaksud pada ayat (1) huruf a diperhitungkan sebagai masa menjalani hukuman. Rehabilitasi bertujuan untuk memulihkan dan/atau mengembangkan kemampuan fisik, mental dan sosial tersangka, terdakwa atau Napi dalam tindak pidana narkotika, atau dengan kata lain tujuan rehab adalah mengedepankan aspek kesehatan terhadap masyarakat pengguna narkotika, dengan dilaksanakan rehab diharapkan tersangka, terdakwa atau Napi dalam tindak pidana Narkotika akan memperbaiki diri.

Menurut Semi Hastuti, SH., selaku Jaksa Penuntut Umum pada Kejaksaan Negeri Yogyakarta, ${ }^{20}$ pelaksanaan rehab bagi pengguna narkotika yang berkeadilan adalah tidak adanya disparitas bagi para pecandu dan/atau korban penyalahguna narkotika dengan didukung ketersediaan anggaran yang cukup. Dan apabila anggaran yang tersedia kurang maka tetap memberikan kesempatan kepada para pecandu dan/atau korban penyalahguna narkotika tanpa dipungut/dibebani biaya. Mekanisme pengawasan yang dilakukan terhadap tersangka selama menjalani rehab dilakukan oleh lembaga rehabilitasi yang menyelenggarakan program rehabilitasi medis dan/atau sosial terhadap tersangka, terdakwa, terpidana dalam penyalahgunaan narkotika dan menyampaikan program rehabilitasi kepada penegak hukum yang meminta dilakukannya rehabilitasi sesuai dengan tingkat proses peradilan.

Usaha Pemerintah Indonesia menuju dekriminalisasi korban pengguna narkotika sebenarnya telah dimulai dengan dikeluarkannya SEMA Nomor 7 Tahun 2009 yang kemudian diganti dengan SEMA Nomor 4 Tahun 2010 tentang Penempatan Penyalahgunaan, Korban Penyalahgunaan dan Pecandu Narkotika ke dalam Lembaga Rehabilitasi Medis dan Rehabilitasi Sosial, yang secara substansial kedua SEMA tersebut tidak ada perubahan. Perbedaan kedua SEMA tersebut hanya terletak pada jumlah barang bukti saja. Pemerintah juga telah mengeluarkan Peraturan Pemerintah Nomor 25 Tahun 2011.

Menurut hemat penulis sesuai dengan teori kieadilan, maka keluarnya SEMA Nomor 4 Tahun 2010 dan Peraturan Pemerintah Nomor 25 Tahun 2011 ini sebenarnya mengukuhkan bahwa pecandu narkotika adalah korban dan bukan pelaku tindak kriminal, sekaligus menjadi legitimasi hukum bahwa pecandu bukanlah pelaku tindak kejahatan melainkan seseorang yang menderita sakit karena kecanduan membutuhkan perawatan baik secara fisik maupun secara psikologis

20 Ibid. 
serta membutuhkan dukungan dari masyarakat untuk dapat kembali hidup normal. Beberapa pejabat negara seperti Kapolri Jenderal Timur Pradopo juga memiliki gagasan yang sama, menurutnya paradigma untuk menempatkan korban pengguna narkotika ke tempat rehabilitasi sebenarnya telah lama disuarakan dan telah ditetapkan dalam Undang-undang Narkotika, dan dalam SEMA Nomor 4 Tahun 2010, tetapi dalam implementasinya belum banyak dilakukan, sehingga sampai sejauh ini korban pengguna narkotika masih harus menjalani proses pengadilan. Para korban pengguna narkotika, menurutnya tidak perlu ditangkap atau dihukum, tetapi para pengguna narkotika lebih perlu diberikan pengobatan di pusat rehabilitasi. Kalau para pengguna narkotika justru ditahan atau dihukum, tidak akan membuat efek jera, bahkan semakin bandel. ${ }^{21}$

Dengan ketentuan tersebut dunia peradilan di Indonesia sebetulnya telah membuka mata tentang hakikat pecandu narkotika dalam konteks ilmu hukum khususnya viktimologi. Sesuatu yang sangat sulit dilegitimasi selama ini, sehingga selama "perang terhadap narkotika" dikumandangkan oleh pemerintah Indonesia, pecandu narkotika selalu ditempatkan sebagai kriminal, maka hak-hak korban untuk mendapatkan pelayanan kesehatan dan perlakuan khusus, dalam hal ini rehabilitasi menjadi hilang. Tantangan ke depan justru berada dalam pundak hakim untuk berani memutus atau menetapkan vonis rehabilitasi terhadap pecandu dan melakukan terobosan hukum serta penemuan hukum yang tidak hanya mengacu pada undang-undang saja, tetapi lebih pada nilai-nilai sosial dan kemanusiaan yang hidup dalam masyarakat.

Dengan demikian, model pemidanaan terhadap korban penyalahgunaan narkotika harus berorientasi pada penyembuhan dan pemulihan, baik melalui lembaga-lembaga medis (rumah sakit dan puskesmas), maupun lembaga sosial, sehingga melahirkan model berupa penanganan yang dapat diterapkan terhadap korban pengguna narkotika. Bentuk penanganan bagi korban pengguna narkotika dapat dilakukan melalui jalur medis (instansi tempat lapor) dan lewat aparat penegak hukum (law enforcement). Jalur medis dalam artian pemerintah menyediakan tempat lapor di masing-masing provinsi, kabupaten/kota maupun kecematan di seluruh Indonesia untuk mencatat dan melaporkan adanya korban pengguna atau pecandu narkotika kemudian membawanya ke pusat-pusat rehabilitasi. Sementara bagi penegak hukum, kepolisian dan/atau BNN sebagai institusi yang memiliki kewenangan berhak menangkap yang selanjutnya membawa langsung korban atau pecandu narkotika yang belum melapor untuk berobat di tempat rehabilitasi sampai sembuh.

${ }^{21}$ Parasian Simanungkalit. (2011). Globalisasi Peredaran Narkotika dan Penanggulangannya di Indonesia. Jakarta: Yayasan Wajar Hidup, hlm. iv 


\section{Kesimpulan}

a. Rehabilitasi bagi pengguna narkotika di Indonesia khususnya di Daerah Istimewa Yogyakarta sudah sesuai dengan hukum positif yang berlaku di Indonesia. Penyidik dapat melakukan rehabilitasi bagi pengguna narkotika berdasar Pasal 54 Undang-undang Nomor 35 Tahun 2009 tentang Narkotika. Tersangka akan dilakukan proses rehabilitasi dalam perkara narkotika, harus terlebih dahulu melalui proses assesment medis dan hukum.

b. Konsep ke depan mengenai pelaksanaan rehabilitasi bagi pengguna narkotika adalah seharusnya terhadap setiap pengguna narkotika yang telah memenuhi persyaratan dalam Pasal 54 Undang-undang Nomor 35 Tahun 2009 tentang Narkotika dan Peraturan Kepala BNN No. 11 Tahun 2014 seluruhnya dilakukan rehabilitasi, tidak ada lagi dilakukan bagi pengguna narkotika dilakukan penahanan di rutan maupun di lembaga pemasyarakatan karena bagi pengguna narkotika bukan solusi. Hal ini dengan tujuan untuk penyembuhan dan pemulihan terhadap pengguna narkotika. Justru dengan dilakukannya rehabilitasi terhadap pengguna narkotika didukung dari keluarga dan masyarakat maka pengguna narkotika lambat laun bisa sembuh dari penggunaan narkotika dan bisa menjadi duta bagi pengguna narkotika.

\section{Daftar Pustaka}

\section{Buku / Literatur}

Danny Yatim. (2011). Kepribadian, Keluarga dan Narkotika, Tinjauan Sosial-Psikologis. Jakarta: Arcan.

Djoko Prakoso, dkk. (2012). Kejahatan-Kejahatan Yang Merugikan dan Membahayakan Negara. Jakarta: Bina Aksara.

Hari Sasangka. (2013). Narkotika dan Psikotropika Dalam Hukum Pidana. Bandung: Mandar Maju.

I Danny Yatim. (2011). Kepribadian, Keluarga dan Narkotika, Tinjauan Sosial-Psikologis. Jakarta: Arcan.

Kusno Adi. (2009). Diversi Sebagai Upaya Alternatif Penanggulangan Tindak Pidana Narkotika Oleh Anak. Malang: UMM Press.

Mukti Fajar ND dan Yulianto Achmad. (2010). Dualisme Penelitian Hukum Normatif dan Empiris. Yogyakarta: Pustaka Pelajar. 
Parasian Simanungkalit. (2011). Globalisasi Peredaran Narkotika dan Penanggulangannya di Indonesia. Jakarta: Yayasan Wajar Hidup.

Redaksi Badan Penerbit Alda. (2003). Menanggulangi Bahaya Narkotika. Jakarta: Amanah R.I/B.P.Alda.

Soedjono Dirdjosisworo. (2010). Hukum Narkotika Indonesia. Bandung: Citra Aditya Bakti. (2010). Narkotika dan Remaja. Bandung: Alumni. (2011). Segi Hukum tentang Narkotika di Indonesia. Bandung: Karya Nusantara.

Soerjono Soekanto. (2010). Pengantar Penelitian Hukum. Jakarta: UI Press.

Sujono AR dan Daniel Bony. (2011). Komentar dan Pembahasan Undang-undang Nomor 35 Tahun 2009 tentang Narkotika. Jakarta: Sinar Grafika.

\section{Jurnal}

Allegra M. Mcleod. (2012). Decarceration Courts, Possibilities and Perils of a Shifting Criminal Law. The Georgetown Law Journal, Vol. 100, No.1587.

James Gilligan. (2012). Punishment Fails, Rehabilitation Works. 19 December 2012, dalam http://www.nytimes.com/roomfordebate/2012/12/18/prison-couldbe-productive/ punishment-fails-rehabilitation-works

\section{Peraturan Perundangan}

Undang-Undang Nomor 22 Tahun 1997 tentang Narkotika 